\title{
ÉPOCAS DE MANEJO QUÍMICO DE COBERTURAS DE SOLO PARA A CULTURA DO FEIJOEIRO EM SISTEMA DE PLANTIO DIRETO NA PALHA
}

\author{
CHEMICAL MANAGEMENT TIME OF SOIL COVER CROPS ON \\ THE COMMON BEAN IN NO-TILLAGE SYSTEM
}

\author{
Maria Helena Elias VALENTINI \\ Orientador: Professor Dr. Pedro RONZELLI JÚNIOR \\ Departamento de Fitotecnia e Fitossanitarismo
}

\begin{abstract}
RESUMO
Na Estação Experimental da Fundação ABC, em Castro, $\mathrm{PR}$, instalou-se um experimento objetivando estudar o efeito de diferentes coberturas de solo, bem como a influência de épocas de manejo químico dessas coberturas sobre o rendimento e componentes de rendimento do feijoeiro. O delineamento experimental adotado foi o de blocos casualizados, em parcelas subdivididas com quatro repetições. Os tratamentos testados foram resultantes das combinações de cinco coberturas de solo (parcelas) e de três épocas de manejo químico (subparcelas). As coberturas vegetais de solo foram: aveia-branca, aveia-preta, azevém, nabo forrageiro e trigo. As três épocas de manejo químico corresponderam à dessecação das coberturas vegetais de solo aos 0,15 e 30 dias antes da semeadura (DAS) da cultura do feijoeiro, variedade 'FT-Bonito'. O plantio das coberturas de solo em até três épocas distintas garantiu a mesma quantidade

de matéria seca das espécies usadas no momento da dessecação química, exceto para o azevém que foi submetido a mais de um corte. O feijoeiro plantado sobre a cobertura de solo azevém foi o que obteve maior população inicial e final. Sobre a aveia-branca foi o que obteve menor população inicial e plantado sobre trigo menor população final. As épocas de manejo 0, 15 e 30 DAS não influenciaram populações inicial e final do feijoeiro. Não houve diferenças no número de vagens por planta, no número de sementes por vagem e no rendimento para as diferentes coberturas de solo e épocas de manejo químico testadas. A massa média de cem sementes foi maior, quando avaliada a época de manejo da cobertura, aos 0 e 15 DAS sobre nabo forrageiro e aveia-preta, aos 15 e 30 DAS sobre aveiabranca, aos 0 e 30 DAS sobre trigo e em qualquer época sobre o azevém.
\end{abstract}

\begin{abstract}
It was carried out, at the $\mathrm{ABC}$ Foundation Experiment Station, Castro, PR, an experiment to study the effects of cover crops, and their chemical management time influence on the yield and components of dry beans. The experimental design was a randomized complete block utilizing split-plots with four replications. The tested treatments were the combination of five cover crops on the plots, and three chemical management times on the split-plots. The cover crops were white oats (Avena sativa), black oats (Avena strigosa), ryegrass (Lollium multiflorum), forage turnip (Raphanus sativus), and wheat (Triticum aestivum) and the chemical management times were 0,15 and 30 days before seedling (DAS) the beans crop 'FT Bonito' variety. Seedling the cover crops in three different limes guarantee the same amount of dry matter at

the moment of species chemical management. An exception occurred with ryegrass that was submitted to an extra cut. Dry beans seeded on ryegrass cover crop showed the best initial and final plant populations. On white oats get the lowest initial plant population and on wheat the lowest final plant population. The chemical management limes did not showed any significant effect on the plant population. It was not verified, on the treatments, any significant difference on the average number of pods per plant, and seeds per pod, and on the yield. The mass average of 100 seeds was affected by the chemical management time and cover crop species. It was higher at 0 and 15 DAS for black oats and forage turnip, at 15 and DAS for white oats, at 0 and 30 DAS for wheat, and it was indifferent for ryegrass.
\end{abstract}

